Note

\title{
Characterization of Mannose Isomerase from a Cellulolytic Actinobacteria Thermobifida fusca MBL10003
}

(Received October 16, 2013; Accepted November 7, 2013)

(J-STAGE Advance Published Date: November 20, 2013)

\author{
Takafumi Kasumi, ${ }^{1, *}$ Sumiko Mori, ${ }^{2}$ Satoshi Kaneko, ${ }^{2}$ Hitoshi Matsumoto, ${ }^{1}$ \\ Yousuke Kobayashi ${ }^{1}$ and Yoshiyuki Koyama ${ }^{2}$ \\ ${ }^{1}$ Enzymology and Molecular Biology Laboratory, Department of Chemistry and Lifescience, Nihon University \\ (1866 Kameino, Fujisawa, Kanagawa 252-0880, Japan) \\ ${ }^{2}$ Biomolecular Engineering Laboratory, National Food Research Institute \\ (2-1-12 Kannondai, Tsukuba, Ibaraki 305-8642, Japan)
}

\begin{abstract}
D-mannose isomerase was cloned and characterized from a newly isolated actinobacteria strain, Thermobifida fusca MBL10003. The structural gene (manI) is predicted to encode a polypeptide of 407 amino acids with an estimated molecular mass of 43,900. Although the identity of the deduced amino acid sequence is not so high $(45.7 \%$ to Salmonella enterica, and $38.5 \%$ to Agrobacterium radiobacter), the catalytic center appears has an essential structure that is conserved in the characterized homologs. It was a dimeric enzyme composed of two active monomer units. The optimal temperature and pH were $60^{\circ} \mathrm{C}$ and 8.0, respectively. The enzyme was stable up to around $60^{\circ} \mathrm{C}$, and between $\mathrm{pH} 4$ and 11 . It showed activity on D-mannose and also on D-lyxose, but not on $\mathrm{N}$-acetyl D-glucosamine, suggesting that it is functionally different from $\mathrm{N}$-acyl D-glucosamine 2-epimerase despite the sequence similarity. Although $K_{\mathrm{m}}$ value for D-mannose, $115 \mathrm{mM}$ was similar to other mannose isomerase, $k$ cat, hence $k$ cat $/ K \mathrm{~m}$ was much higher than those. The enzyme was significantly inhibited by such divalent metal ions as $\mathrm{Cu}^{2+}, \mathrm{Cd}^{2+}$ or $\mathrm{Ca}^{2+}$, but it was not a metal-required enzyme for activity emergence.
\end{abstract}

Key words: mannose isomerase, $N$-acyl D-glucosamine 2-epimerase, Thermobifida fusca MBL10003

Mannose isomerase (EC 5.3.1.7) is one of the aldo-keto isomerase that can catalyze isomerization between mannose and fructose. Reaction equilibrium is shifted to mannose at a ratio of $c a .70$ to $30 .{ }^{1)}$ This enzyme has been known inducibly produced by several microorganisms when D-mannose is supplied as a carbon source. Mannose isomerase is therefore, derepressed enzyme like xylose isomerase ${ }^{2)}$ or galactose dehydrogenase ${ }^{3)}$ that is acquired through a release of glucose catabolite repression. ${ }^{4,5)}$ A mutant of Escherichia coli $\mathrm{K} 12$ selected for growth on D-lyxose produced a D-mannose isomerase constitutively, ${ }^{6}$ but D-mannose is normally transported into E. coli $\mathrm{K} 12$ by the phosphatetransferase system $^{7)}$ as D-mannose-6-phosphate. ${ }^{8)}$ Hence, these enzymes were suggested to be possible evolutionary remnants. ${ }^{9)}$

Meanwhile, mannose has been paid attention from basic and practical aspect owing to its specific characteristics. Generally, sugar chains associated with molecular recognition of immune cells, erythrocytes and allergenic crossreacting carbohydrate determinants consist of a significant amount of manno-oligosaccharides. ${ }^{10)}$ Mannose itself protects infection from Salmonella thyphimillium to chicken in poultry farming. ${ }^{11,12)}$ Mannose is thus potent aldo-hexose on medical, pharmaceutical and food-biochemical fields. However, expensiveness of this sugar compared with other

*Corresponding author (Tel. \& Fax. +81-466-84-3943, E-mail: kasumi@brs.nihon-u.ac.jp).

Abbreviation: manI, mannose isomerase gene. commercially available sugar is serious bottleneck for wide utilization at present. The enzymatic conversion from inexpensively available fructose by mannose isomerase is one of the promising methods for a practical scale production of mannose.

Until now, mannose isomerases from several microorganisms such as Pseudomonas saccharophila, ${ }^{1)}$ Streptomyces aerocolonigenes, ${ }^{13)}$ Escherichia coli,${ }^{14)}$ Pseudomonas cepacia ${ }^{15)}$ or Pseudomonas sp. ${ }^{16)}$ have been reported, and also enzymatic conversion of mannose from fructose have been tried using the mannose isomerases from $P$. cepacia ${ }^{17)}$ or Pseudomonas sp. ${ }^{16)}$. On the other hand, there are only a few reports on genetic description of this enzyme.

Thermobifida fusca is a moderately thermophilic bacteria belonging to actinobacteria. It is known as a major degrader of plant cell wall material in rotting hay, compost heap, or manure piles since it can produces a wide variety of extracellular glycoside-hydrolyzing enzymes. Recently, the complete genome of the T. fusca YX strain has been sequenced and annotated. ${ }^{18)}$ To bring a new insight into the matter concerned, we have been studying on T. fusca MBL10003, a novel strain of Thermobifida fusca that was originally screened and isolated from soil sample by Meiji Co., Ltd. (Tokyo, Japan), ${ }^{19,20)}$ This actinobacteria was originally identified as mannose isomerase-producing microorganism that grew well at $50-60^{\circ} \mathrm{C}$. Here, we characterized the mannose isomerase from T. fusca MBL10003 on molecular basis, and evaluated it in comparison to other mannose isomerases 
derived from a variety of microbial sources.

A sequence of the gene encoding T. fusca MBL10003 mannose isomerase was determined as follows. First, a 453 bp gene fragment was obtained by PCR using forward and reverse primer designed from $\mathrm{N}$-terminal amino acid sequences of the enzyme purified with sequential five step (DEAE-Sepharose, Resource ISO, Resource PHE, DEAECOSMOgel and Superdex 200HR, Pharmacia AB., Uppsala, Sweden) column chromatography, and also its end-proteinase Glu-C digested fragment. ${ }^{21)}$ Then, unknown 5'- and 3'regions were amplified by three step thermal asymmetric interlaced PCR (TAIL-PCR) ${ }^{22,23)}$ using combination of three sets of forward and reverse long specific primers, and three short arbitrary degenerate primers designed from the gene fragment sequence above, MBL10003 genomic DNA as template prepared with an Insta-Gene Matrix DNA preparation kit (Bio-Rad Laboratories Inc., Hercules, USA), TaKaRa LA Taq Polymerase, and GC buffer (Takara Bio Inc., Tokyo, Japan).

Finally, PCR was performed using forward (5'-CCTCCACGCGGCGCCGTGCGCGTATGCCGTTC-3') and reverse (5'-CCATTCCCGGCCTGCCCCGGCCGGGCGCGCGG-3') primer designed according to the sequence of TAIL-PCR fragment, genomic DNA as template, TaKaRa LA Taq Polymerase, and LA PCR buffer (Takara Bio Inc.). The DNA fragment obtained thus, was confirmed as a whole T. fusca MBL 10003 mannose isomerase gene (manl) through sequence analysis with $\mathrm{ABI}$ sequence analyzer (PerkinElmer Japan Co., Ltd., Tokyo, Japan). To obtain recombinant manI gene, $N c o$ I and XhoI cleavage sites were inserted in upstream and downstream of the gene respectively, using PCR amplification with the specific primer set,
MBL10003 genomic DNA as template, TaKaRa LA Taq Polymerase, and GC buffer for 15 amplification cycles that consisted of denaturation at $98^{\circ} \mathrm{C}$ for $1 \mathrm{~min}$, annealing at $74^{\circ} \mathrm{C}$ for $1.5 \mathrm{~min}$, and extension at $72^{\circ} \mathrm{C}$ for $10 \mathrm{~min}$. The resulting PCR products were ligated to the pET-30a (+) vector (Novagen Inc., Madison, USA) between the NcoI and XhoI site, yielding p30MITF, a plasmid carrying the manI gene of T. fusca MBL10003. The plasmid was transferred into $E$. coli BL21 Gold (Stratagene Inc., La Jolla, USA) by electroporation with an E. coli Pulser (Bio-Rad Laboratories Inc.) in a $0.1 \mathrm{~cm}$ cuvette at $1.80 \mathrm{kV}$. Transformants were cultured at $37^{\circ} \mathrm{C}$ in $\mathrm{LB}$ medium containing $50 \mu \mathrm{g} / \mathrm{mL}$ kanamycin until $\mathrm{OD}_{600}$ reached approximately 0.5 . After addition of isopropyl- $\beta$-D-thiogalactopyranoside to a final concentration of $0.1 \mathrm{mM}$, the cultures were grown for $21 \mathrm{~h}$ at $20^{\circ} \mathrm{C}$ on a rotary shaker at $150 \mathrm{rpm}$.

The deduced amino acid sequence encoded by the mannose isomerase gene, manI, from Thermobifida fusca MBL10003 was compared to homologs from other microbial strains (Fig. 1). The gene consists of 1,221 bp that is predicted to encode 407 amino acids with an estimated molecular mass of 43,900. The GC content, $72 \%$, was considerably high, as is the case of actinobacteria.

In the T. fusca YX genome data base, the gene homologous to mannose isomerase is assigned as a putative protein. ${ }^{18)}$ Comparing the sequence obtained from T. fusca MBL10003 with the published sequence, there was only one amino acid substitution (Ser-26 in YX is substituted with Ala-26 in MBL10003) between these two genes. Hence, both genes are predicted to encode almost the same amino acid sequence. The accession number of manI gene of $T$. fusca MBL10003 was assigned as AB761401 in DDBJ/
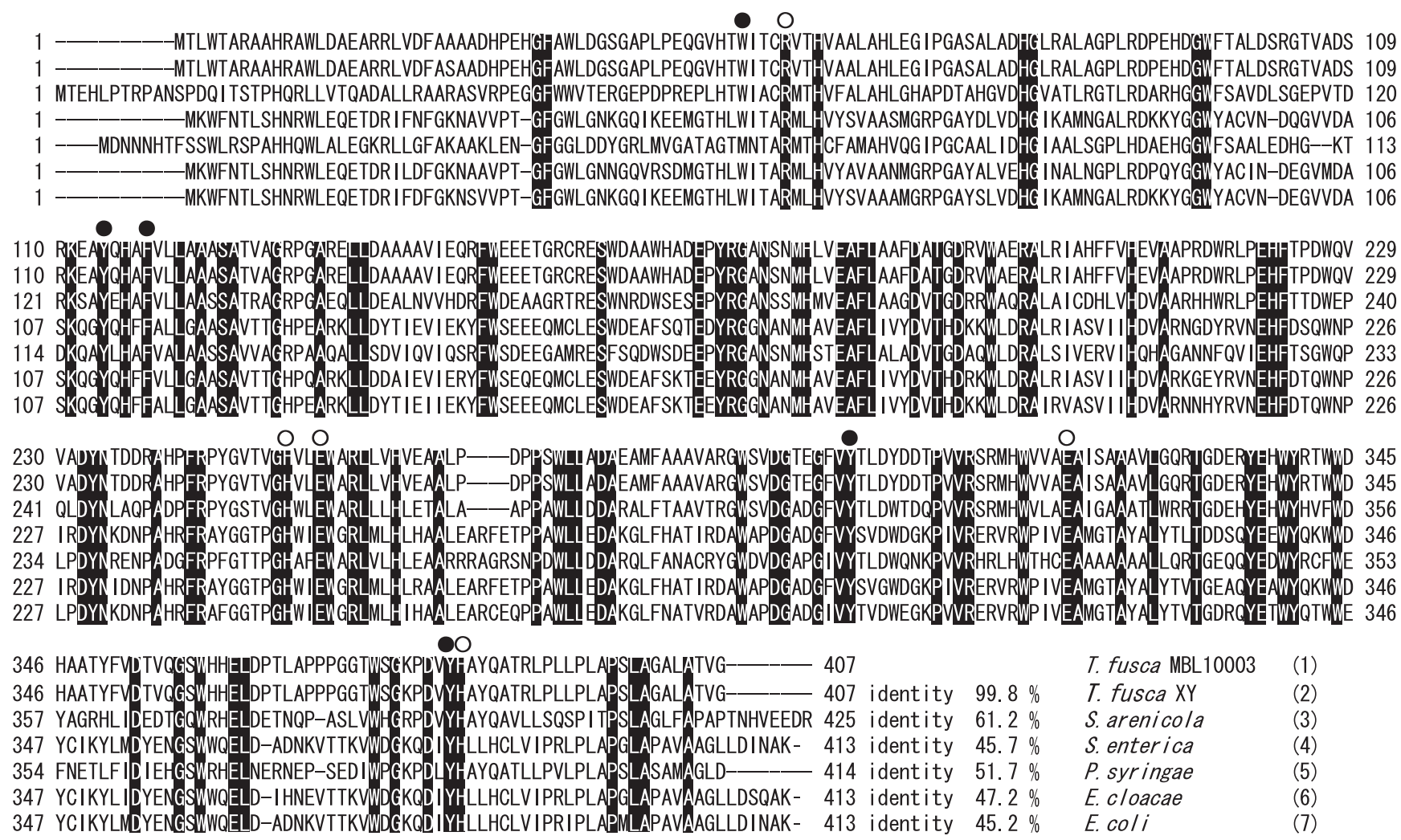

Fig. 1. Comparison of amino acid sequences of mannose isomerases from several bacteria.

, catalytic residue; 9 , substrate binding residue. (1) Thermobifida fusca MBL 10003; (2) Thermobifida fusca YX (assigned as a putative protein in genome date base); (3) Salinispora arenicola; (4) Salmonella enterica: (5) Pseudomonas syringae; (6) Enterobacter; (7) Escherichia coli. 
EMBL/Genbank data base. The predicted amino acid sequence of mannose isomerase was $45.7 \%$ identical to amino acid sequence of YihS (mannose isomerase) from Salmonella enterica ${ }^{24)}$ and $38.5 \%$ identical to $A$. radiobacter. ${ }^{25}$ ) Based on the three-dimensional structure shown in $S$. enterica mannose isomerase, ${ }^{24)}$ five amino acid residues in T. fusca, Trp-53, Tyr-114, Phe-118, Tyr-299, Tyr-382 are demonstrably involved in substrate binding, and contributing to the formation of deep cleft. Five amino acid residues, His-251, His-383, Arg-57, Glu-254, Glu-319 are essential for enzyme catalysis, and His-251 is thought to function as a base catalyst responsible for transferring the proton from $\mathrm{C} 1$ to $\mathrm{C} 2$ position in the isomerization step. Similar to $S$. enterica mannose isomerase, metal binding residues were not observed in amino acid sequence of $T$. fusca mannose isomerase. In $S$. enterica, the transient intermediate between aldo-keto interconversion was proposed as a cis-enediol due to a lack of metal bindng residues. However, we obtained different results as to the enzyme from T. fusca (data not shown). His-383 may act for pyranose ring opening through the deprotonation of $\mathrm{O} 1$ atom and protonation of $\mathrm{O} 5$ atom in corporation with Glu-254. Thus, despite the overall level of amino acid identity among mannose isomerases, the catalytic center appears have an essential structure that is conserved in the characterized homologs.

E. coil transformants harboring a plasmid encoding $T$. fusca manI (p30XITF) were harvested by centrifugation and then disrupted by sonication for $3 \mathrm{~min}$. Cell-free extract was collected by centrifugation of the sonicate at 8,000 $\times \mathrm{G}$ for $10 \mathrm{~min}$, and then salted out with $80 \% \mathrm{NH}_{2} \mathrm{SO}_{4}$. The preparation was dialyzed against $50 \mathrm{mM}$ phosphate buffer, and a crude recombinant mannose isomerase preparation was applied to a $5 \times 50 \mathrm{~mm} \mathrm{Ni-nitrilotriacetic} \mathrm{acid} \mathrm{(NTA)}$ agarose column (Qiagen $\mathrm{GmbH}$, Hilden, Germany) for further purification. Mannose isomerase was eluted from the column with a linear gradient of 0.04 to $0.2 \mathrm{M}$ imidazole in $50 \mathrm{mM}$ phosphate buffer, $\mathrm{pH} 7.3$ at a flow rate of $1 \mathrm{~mL} / \mathrm{min}$. Recombinant T. fusca mannose isomerase was purified to homogeneity from the E. coil extracts by NTA affinity chromatography, and proteins in each preparation or fraction were separated by SDS-PAGE. Through one-step affinity column chromatography, the enzyme was purified to a single

(a)

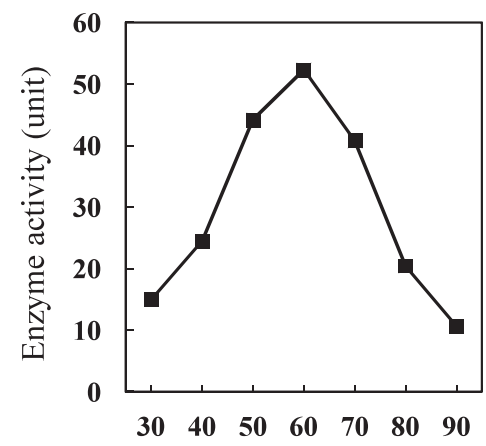

Temperature $\left({ }^{\circ} \mathrm{C}\right)$ band on SDS-PAGE of $10 \%$ gel, the protein had an estimated molecular mass of $41 \mathrm{kD}$, the same value calculated from amino acid component. While, molecular mass obtaind from gel filtration using Superdex 75 (GE Healthcare Bio-Sciences Corp., Piscataway, USA) was $89 \mathrm{kD}$, indicating that $T$. fusca mannose isomerase was a dimer. One other peak appeared in gel filtration chromatography at molecular mass of $48 \mathrm{kD}$ was estimated as a monomeric enzyme, which had 60-70\% mannose isomerase activity compared with dimer fraction. E. coli enzyme has been reported to be a tetramer and dissociated into a dimer with $\mathrm{NaSO}_{4}$ treatment. ${ }^{15)}$ Contrast to this, dissociation into a monomer with $\mathrm{NaSO}_{4}$ was not observed in $T$. fusca enzyme.

The reaction mixture used to measure recombinant mannose isomerase activity consists of $50 \mu \mathrm{L}$ of $0.4 \mathrm{M}$ mannose (final concentration $50 \mathrm{mM}$ ), $100 \mu \mathrm{L}$ of $0.2 \%$ bovine serum albumin, $35 \mu \mathrm{L}$ of $4 \mathrm{mM} \mathrm{MgCl}_{2}, 200 \mu \mathrm{l}$ of 50 $\mathrm{mM}$ phosphate buffer, $\mathrm{pH} 7.5$, an appropriate amount of enzyme preparation, and distilled water in a total volume of $400 \mu \mathrm{L}$. Following incubation at $50^{\circ} \mathrm{C}$ for $10 \mathrm{~min}$, the reaction mixture was immediately put on a heating block to stop the reaction. After removal of the precipitate by centrifugation at $12,000 \times \mathrm{G}$ for $3 \mathrm{~min}$, the supernatant was assayed for fructose content using a cysteine-carbazole-sulfuric acid method. ${ }^{26)}$ One unit of enzyme activity was defined as one micromole of fructose formed per minute. In case of $N$-acyl glucosamine 2-epimerase activity, $\mathrm{N}$-acetyl mannosamine formed from $\mathrm{N}$-acetyl glucosamine as substrate was measured using ICS-3000 (DIONEX) chromatographic system with a Carbo pac PA-1 column.

The enzyme activity of sonicated cell suspension of transformant $E$. coli, 7,550 U/g dry cell was 755 times as higher as that of the wild T. fusca MBL10003, $10 \mathrm{U} / \mathrm{g}$ dry cell. The temperature dependence of the enzyme activity was measured at each temperature from 30 to $90^{\circ} \mathrm{C}$. The thermal stability of the enzyme was determined by measuring the residual activity following pre-incubation in the range from 30 to $90^{\circ} \mathrm{C}$. The thermal profile and $\mathrm{pH}$ dependences of the T. fusca mannose isomerase are shown in Figs. 2 and 3, respectively. The optimum reaction temperature was approximately $60^{\circ} \mathrm{C}$, and the optimum reaction $\mathrm{pH}$ appeared to be around $\mathrm{pH}$ 8.0. The enzyme was stable up to $60^{\circ} \mathrm{C}$, and also stable between $\mathrm{pH} 4$ and 11 . These features

(b)

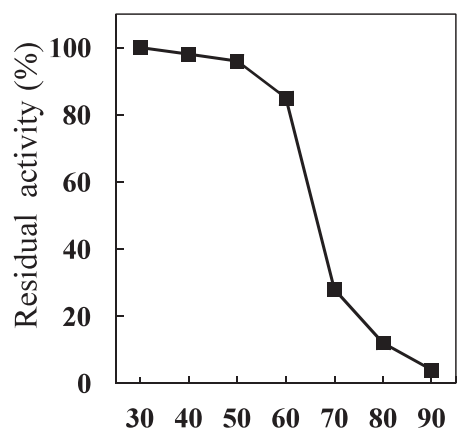

Temperature $\left({ }^{\circ} \mathrm{C}\right)$

Fig. 2. Effect of temperature on mannose isomerase.

(a) Effect of temperature on enzyme activity: activity was measured over $10 \mathrm{~min}$ at each temperature at $\mathrm{pH} 7.5$. (b) Heat stability: after pre-incubation at each temperature, residual activity over $10 \mathrm{~min}$ at $50^{\circ} \mathrm{C}$ was measured at $\mathrm{pH} 7.5$. 
(a)

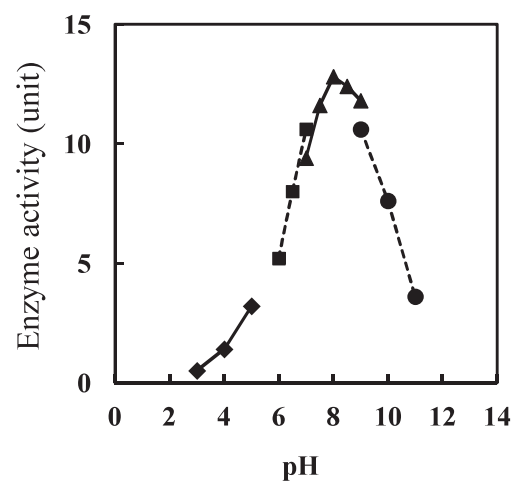

(b)

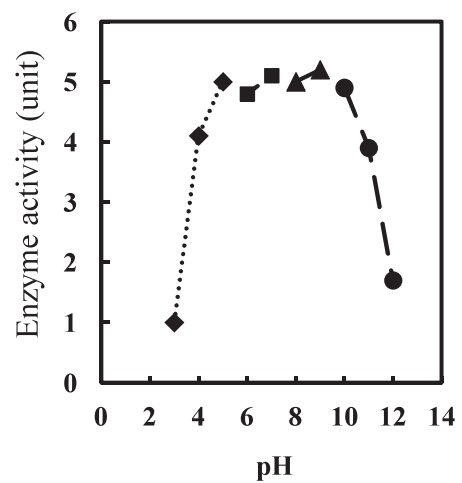

Fig. 3. Effect of $\mathrm{pH}$ on mannose isomerase.

(a) Effect of $\mathrm{pH}$ on enzyme activity: activity over 10 min was measured at each pH. (b) $\mathrm{pH}$ stability of enzyme: after pre-incubation at each $\mathrm{pH}$ for $10 \mathrm{~min}$, residual enzyme activity was measured over $10 \mathrm{~min}$ at $\mathrm{pH}$ 7.5. MacILvaine; $\boldsymbol{\square}$, Na phosphate; $\boldsymbol{\Delta}$, Tris- $\mathrm{HCl}$; $\bigcirc$, Glycine-HCl; concentration of each buffer is $50 \mathrm{mM}$.

are similar to those of most mannose isomerases described to date.

We examined seven sugars as potential substrates of $T$. fusca mannose isomerase. Among sugars tesed, D-mannose (69.2 U/mg) and D-lyxose (18.0 U/mg) acted as substrates of $T$. fusca mannose isomerase. In contrast, the other sugars (hexoses: L-glucose, D-galactose, $N$-acetyl D-glucosamine, or pentoses: L-arabinose, D-xylose) little acted as substrates for this enzyme. These results suggested that the T. fusca enzyme is functionally different from $N$-acyl D-glucosamine 2- epimerase in spite of homologous amino acid sequence. Substrate specificity of the T. fusca enzyme was similar to other microbial mannose isomerases; however, the kinetic parameters of the enzyme were clearly different. The kinetic parameters of recombinant mannose isomerase for mannose and lyxose are summarized in the Table 1 . The $K \mathrm{~m}$ values for mannose and lyxose; 115 and $537 \mathrm{mM}$, respectively, were almost the same as those of $E$. coli mannose isomerase; 108 and $405 \mathrm{mM}$, respectively. ${ }^{24)}$ In contrast, the $k$ cat and, therefore, $k \mathrm{cat} / \mathrm{Km}$ of the $T$. fusca mannose isomerase for mannose was approximately 30 -fold larger than those of $E$. coli mannose isomerase. Thus, $T$. fusca mannose isomerase is demonstrated to be highly active than the other homologs with respect to the rate constant rather than the affinity constant. T. fusca MBL10003 is a strain originally exploited and isolated as mannose isomerase-producing microorganism, hence, the results obtained might be reasonable. The enzyme activity was considerably inhibited by the addition of divalent metal ions such as $\mathrm{Cu}^{2+} ; 37 \%, \mathrm{Cd}^{2+} ; 45 \%$, and $\mathrm{Ca}^{2+} ; 20 \%$. Other metal ions examined; $\mathrm{Mg}^{2+}, \mathrm{Co}^{2+}, \mathrm{Mn}^{2+}$, $\mathrm{Zn}^{2+}, \mathrm{Pb}^{2+}$, and also EDTA showed no siginificant effect on the enzyme activity. It was therefore considered that T. fusca mannose isomerase was not a metal-required enzyme. This can be successfully supported by amino acid sequence analysis, in which metal binding residues are not demonstrably found similar to the enzyme from $S$. enterica. ${ }^{24)}$

The reaction equilibrium of enzyme-catalyzed isomerization between mannose and fructose was determined using each sugar as a substrate over a long time span. The reactions proceeded with time and finally reached equilibrium points of approximately mannose; $25 \%$ and fructose; $75 \%$ both from fructose and mannose as starting substrates. This findings indicated that the T. fusca mannose isomerase had
Table 1. Substrate specificity of mannose isomerase.

\begin{tabular}{lc}
\hline \multicolumn{1}{c}{ Substrate } & Relative activity (\%) \\
\hline D-Mannose & 100 \\
D-Lyxose & 26.6 \\
D-Galactose & 2.0 \\
D-Arabinose & 1.8 \\
D-Xylose & $<1.0$ \\
D-Glucose & $<1.0$ \\
$N$-Acetyl glucosamine & $<1.0$
\end{tabular}

Ketose formed from corresponding aldose through enzymatic activity was measured colorimetrically using a cysteine-carbazole $\mathrm{H}_{2} \mathrm{SO}_{4}$ method. In case of $\mathrm{N}$-acyl glucosamine 2-epimerase activity, $\mathrm{N}$-acetyl mannosamine formed from $\mathrm{N}$-acetyl glucosamine as substrate was measured using ICS-3000(DIONEX) chromatographic system with a Carbo pac PA-1 column.

Table 2. Kinetic constants of mannose isomerase.

\begin{tabular}{lcc}
\hline Kinetic parameter & D-Mannose & D-Lyxose \\
\hline$K_{\mathrm{m}}(\mathrm{mM})$ & $115 \pm 15$ & $537 \pm 12$ \\
$V_{\max }\left(\mathrm{mM} \cdot \mathrm{s}^{-1}\right)$ & $0.0116 \pm 0.0006$ & $0.00186 \pm 0.00019$ \\
$k_{\mathrm{cat}}\left(\mathrm{S}^{-1}\right)$ & $788 \pm 40$ & $63.3 \pm 6.5$ \\
$k_{\mathrm{cat}} / K \mathrm{~m}\left(\mathrm{mM}^{-1} \cdot \mathrm{s}^{-1}\right)$ & $6.85 \pm 0.20$ & $0.118 \pm 0.009$ \\
\hline
\end{tabular}

higher affinity toward fructose than mannose, similar to other mannose isomerase hitherto described.

The low conversion ratio of mannose like this, seemes to be one of the bottlenecks for applicable production of mannose with mannose isomerase. It is therefore necessary to increase the mannose content of the product following enzymatic isomerization process. For this purpose, separation of mannose and fructose has been tried using membrane bioreactor combined to resin. ${ }^{27)}$ Continuous reaction process with immobilized enzyme preparation has also been proposed to increase efficiency of the enzyme. ${ }^{17,27)}$ Anyway, In addition to basic enzymatic characterization, bio-process technologies like these are expected to develop for a wide variety of utilization of this promising sugar.

\section{ACKNOWLEDGMENTS}

We thank Drs. Satoshi Hanamura and Yuichi Satoh, Meiji Co., Ltd., for their kind and useful advice, and discussion. 


\section{REFERENCES}

1 ) N.J. Palleroni and M. Doudoroff: Mannose isomerase of Pseudomonas saccharophila. J. Biol. Chem., 218, 535-548 (1956).

2 ) R.O. Marshall and E.R. Kooi: Enzymatic conversion of D-glucose to D-fructose. Science, 125, 648 (1957).

3 ) T.T. Wu: Growth on D-arabitol of a mutant strain of Escherichia coli $\mathrm{K} 12$ using a novel dehydrogenase and enzymes related to L-1,2-propanediol and D-xylose metabolism. J. Gen. Microbiol., 94, 246-256 (1976).

4 ) H.M. Kalckar, K. Kurihashi and E. Jordan: Heredity defects in galactose metabolism in Escherichia coli mutants. I. Determination of enzyme activity. Proc. Natl. Acad. Sci. USA, 45, 1775-1786 (1959).

5 ) M.B. Yamolinsky, H. Wiesmeyer, H.M. Kalckar and E. Jordan: Heredity defects in galactose metabolism in Escherichia coli mutants. II. Galactose-induced sensitivity. Proc. Natl. Acad. Sci. USA, 45, 1786-1791 (1959).

6 ) F.J. Stevens and T.T. Wu: Growth on D-Lyxose of a mutant strain of Escherichia coli $\mathrm{K} 12$ using a novel isomerase and enzymes related to D-xylose metabolism. J. Gen. Microbiol., 97, 257-265 (1976).

7 ) W. Kunding, F.D. Kunding, B. Anderson and S. Roseman: Restoration of active transport of glycosides in $E$. coli by a component of a phosphotransferase system. J. Biol. Chem., 241, 3243-3246 (1966).

8 ) A. Markovitz, R.J. Sydiskis and M.M. Lieberman: Genetic and biochemical studies on mannose-negative mutants that are deficient in phosphomannose isomerase in Escherichia coli $\mathrm{K} 12$. J. Bacteriol., 94, 1492-1496 (1967).

9 ) T.T. Wu: Experimental evolution in bacteria. CRC Crit. Gen. Rev. Microbiol., 6, 33-51(1978).

10) F. Altmann: Structures of the N-linked carbohydrate of ascorbic acid oxidase from zucchini. Glycoconj. J., 15, 79-82 (1998).

11) B.A. Oyofo, R.E. Droleskey, J.O. Norman, H.H. Mollenhauer, R.L. Ziprin, D.E. Corrier and J.R. DeLoach: Inhibition by mannose of in vitro colonization of chicken small intestine by Salmonella typhimurium. Poult. Sci., 68, 1351-1356 (1989).

12) B.A. Oyofo, J.R. Deloach, D.E. Corrier, J.O. Norman, R.L. Ziprin and H.H. Mollenhauer: Prevention of Salmonella typhimurium colonization of broilers with D-mannose. Poult. Sci., 68, 1357-1360 (1989).

13) Y. Takasaki: Kinetic and equilibrium studies on D-mannose-Dfructose isomerization by mannose isomerase from Streptomyces aerocolonigenes. Agric. Biol. Chem., 311, 435-440 (1967).

14) F.T. Stevens, P.W. Stevens, J.G. Hovis and T.T. Wu: Some properties of D-mannose isomerase from Escherichia coli K12. J. Gen. Microbiol., 124, 219-223 (1981).
15) P. Allenz, Y.E. Lee and T.G. Lessie: Enzyme related to fructose utilization in Pseudomonas cepacia.J. Bacteriol., 150, 1348-1356 (1982).

16) Y. Takasaki, K. Hinoki, Y. Kataoka, S. Fukuyama, N. Nishimura, S. Hayashi and K. Imada: Enzymatic production of D-mannose from D-fructose by mannose isomerase. J. Ferment. Bioeng., 76, 237-239 (1993).

17) P. Allenz, M.J. Morrell and R.W. Detroy: Conversion of mannose to fructose by immobilized mannose isomerase from Pseudomonas cepacia. Appl. Biochem. Biotechnol., 24/25, 171-182 (1990).

18) A. Lykidis, Mavromaris, N. Ivanova, I. Anderson, M. Land, G. DiBartolo, M. Martinez, A. Lapidus, S. Lucas, A. Copeland, P. Richardson, D.B. Wilson and N. Krypides: Genome sequence and analysis of the soil cellulolytic Actinomycete Thermobifida fusca YX. J. Bacteriol., 189, 2477-2486 (2007).

19) Meiji Co., Ltd., H. Nakamura, T, Nishimura, T. Hamaya and M. Hirayama: A novel mannose isomerase and production method of mannose using it. Japan Patent 11-75836 (1999).

20) T. Kasumi, S. Mori, S. Kaneko and Y. Koyama: Molecular Cloning of xylose isomerase from a novel actinobacteria strain, Thermobifida fusca MBL10003. J. Appl. Glycosci., 59, 43-46 (2012).

21) D.W. Cleveland, S.G. Fisher, M.W. Kirshner and U.K. Laemmli: Peptide mapping by limited proteolysis in sodium dodecyl sulfate and analysis by gel. J. Biol. Chem., 252, 1102-1106 (1977).

22) Y-G. Liu, N, Mitukawa, T. Oosumi and R.F. Whitter, Efficient isolation and mapping of Arabidopsis thaliana T-DNA insert junction by thermal asymmetric interlaced PCR. Plant J., 8, 457-463 (1995).

23) Y-G Liu and R.F. Whitter: Thermal asymmetric interlaced PCR: autamable amplification and sequencing of insert end fragment from P1 and YAC clones for chromosome walking. Genomics, 25, 674-681 (1995).

24) T. Ito, B. Mikami, W. Hashimoto and K. Murata: Crystal structure of YihS in complex with D-mannose stuctural annotation of Escherichia coli and Salmonella enterica yihS-encoded proteins to an aldose-ketose isomerase. J. Mol. Biol., 377,1443-1459 (2008).

25) Showa Sangyo Co., Ltd., Y. Inoue, N. Fushimi, H. Mizubuchi, K. Okamoto and S. Miyoshi: Mannose isomerase gene. WOo1/025443 (2001).

26) Z. Dishe and E. Borenfreund: A new spectrophotometric method for the detection of keto sugars and trioses. J. Biol. Chem., 192, 583-587 (1951).

27) J. Hirose, Y. Kinoshita, S. Fukuyama, S. Hayashi, H. Yokoi and Y. Takasaki: Continous isomerization of D-fructose to D-mannose by immobilized Agrobacterium radiobacter cells. Biotechnol. Lett., 25, 349-352 (2003). 